Canadian University Music Review

Revue de musique des universités canadiennes

James McKinnon, ed. Antiquity and the Middle Ages: From

Ancient Greece to the 15th Century. Music and Society.

Englewood Cliffs: New Jersey, 1990. x, 337 pp. ISBN 0-13-036153-4

(hardcover), ISBN 0-13-036161-5 (paperback)

\title{
Terry Brown
}

Numéro 15, 1995

URI : https://id.erudit.org/iderudit/1014400ar

DOI : https://doi.org/10.7202/1014400ar

Aller au sommaire du numéro

\section{Éditeur(s)}

Canadian University Music Society / Société de musique des universités canadiennes

\section{ISSN}

0710-0353 (imprimé)

2291-2436 (numérique)

Découvrir la revue

\section{Citer ce compte rendu}

Brown, T. (1995). Compte rendu de [James McKinnon, ed. Antiquity and the Middle Ages: From Ancient Greece to the 15th Century. Music and Society. Englewood Cliffs: New Jersey, 1990. x, 337 pp. ISBN 0-13-036153-4 (hardcover), ISBN 0-13-036161-5 (paperback)]. Canadian University Music Review / Revue de musique des universités canadiennes, (15), 159-161.

https://doi.org/10.7202/1014400ar

All Rights Reserved (C Canadian University Music Society / Société de musique des universités canadiennes, 1995
Ce document est protégé par la loi sur le droit d'auteur. L’utilisation des services d'Érudit (y compris la reproduction) est assujettie à sa politique d'utilisation que vous pouvez consulter en ligne.

https://apropos.erudit.org/fr/usagers/politique-dutilisation/ 
natory connotations. Thereafter, the series title of Music and Society was adopted for North American distribution, while the original series title has been retained in Europe. Thus, the change of the general title does not represent any change in approach in the series; all eight of the volume editors worked from the same set of governing principles.

Paul F. Rice

James McKinnon, ed. Antiquity and the Middle Ages: From Ancient Greece to the 15th Century. Music and Society. Englewood Cliffs: New Jersey, 1990. x, 337 pp. ISBN 0-13-036153-4 (hardcover), ISBN 0-13-036161-5 (paperback).

1. James McKinnon: "Early Western Civilisation"; 2. Andrew Barker: "Public Music as 'Fine Art' in Archaic Greece"; 3. James McKinnon: "Christian Antiquity"; 4. James McKinnon: "The Emergence of Gregorian Chant in the Carolingian Era"; 5. David Hiley: "Plainchant Transfigured: Innovation and Reformation throught the Ages"; 6. Marion S. Gushee: "The Polyphonic Music of the Medieval Monastery, Cathedral and University"; 7. Peter M. Lefferts: "Medieval England, 950-1450"; 8. Christopher Page: "Court and City in France, 1100-1300"; 9. Daniel Leech-Wilkinson: "Ars Antiqua - Ars Nova - Ars Subtilior"; 10. Michael Long: "Trecento Italy"; 11. Reinhard Strohm: "The Close of the Middle Ages".

Few would question the need for a book designed to illuminate the relationship between music and society before the Renaissance. Of all music's stylistic periods, the Middle Ages is arguably the one for which this relationship remains most dimly perceptible. Medieval studies in music have been preoccupied with sources and texts (both musical and theoretical) because there were so many to be worked through, and because there are so few which easily furnish much information about the societies from which they emerged. Unfortunately, it must be questioned whether this volume really represents much of an advance. It succeeds in so far as revealing how much remains to be learned, or at least, hypothesized, and in highlighting many of the questions which scholarship has neglected or failed to explore. In fairness, it must be pointed out that it is much easier to identify such questions than to find answers, or even to know where to look.

Contrary to what the series' Preface and dust-jacket material promise, a good deal of the volume consists of historical survey - "what happened" - ignoring the promises about the "why it happened" (ix). David Hiley's chapter on medieval plainsong creates a long series of frustrations, describing or mention- 
ing the versus, cantiones, Feast of Fools, liturgical drama, and saints' offices without apparently considering the ideas of social function and meaning. Like Daniel Leech-Wilkinson's chapter on later continental polyphony, it is long on Manuscripts and short on Man. Similarly, Marion Gushee discusses instructions for the use of polyphony for processions without mentioning the very great civic and religious significance these events held. Surely the link between special occasions and special styles is what should be of interest in a book with this one's stated aims. Both Gushee and Peter Lefferts (on English Music) gloss over the intriguing similarity of certain polyphonic styles to dance music and folk polyphony, ignoring the interactions between sacred and secular music and musicians.

Michael Long's essay on the Trecento surveys styles and genres. He considers "Italian awareness of French musical culture" (252) but not the relations of Italian people with the French, or even their appetite for French songs. Long also makes offhand mention of the effect on the madrigal of "Florence's republican social milieu" (254). The reader is presumed to know what the implications of that milieu were, and it is not shown how the effect occurred. Yet documentation for, and modern interpretations of, Florentine society are in fact both exceedingly rich; work on the confraternities and the laude spirituali comes to mind. This essay, like much of the rest of the book, is often effective in its traditional discussion of "high" cultural interaction, but it gets weaker as it moves toward the properly societal. There is virtually nothing in any of the essays resembling a harmonization of musical with social theory; indeed, the latter itself is overwhelmingly absent.

This collection, its intentions aside, is a less technical, somewhat more "cultural" standard history. On these terms, most of the chapters are very good. Some even bring forward new interpretations of evidence, most notably editor James McKinnon's revival (in his chapter on early chant) of the argument that Gregory II, and not Gregory I, was the pope instrumental in consolidating chant practice. Elsewhere are some flashes of what the volume hoped to accomplish, such as Gushee's suggestion that the "worldly atmosphere" of Limoges changed the direction of polyphonic composition (and perhaps reduced the reliance on chant tenors) in Aquitaine (154).

To conclude on a positive note, I will cite three sections of the volume which stand apart from the rest in successfully fulfilling its mandate. McKinnon's introductory essay on "Early Western Civilization" is (as his two chapters on chant are not) a lively read, and is probably as good a survey of two thousand years' history and musical culture as is possible in forty-three pages. Andrew Barker's essay on Greece (and Rome), whether intended for the general reader or not, can easily be recommended to musicians and scholars who are less 
familiar with ancient music than they might wish to be. Perhaps he has the advantage that, in contrast to the Middle Ages, so much material survives on the context for music, with so little actual music to get in the way. Barker's verdict on Plato's "pious twaddle" and reactionary griping about declining music values (63) in The Republic and Laws is refreshing. Under the rubric of Plus ça change ..., his conclusion that Plato's ostensibly aesthetic dismay was really due to a new separation of musical and social values shows us how the events of a few years ago relating to pop music, Tipper Gore, and the American Senate hearings grew out of a very ancient conflict.

Finally, Christopher Page's magnificent essay on the Troubadours and Trouveres is exactly what one hoped to find. He largely ignores the genres, sources, even the names - matters he trusts us to learn about elsewhere - and instead takes us into their world through equal measures of solid research and letting their poetry speak. Fascinating pictures of persons and lives emerge. In this context, the episode comparing the otherwise pious girls who "run free and dance caroles" to aristocrats' dogs fighting with their fellows in town when they get the chance is worth any number of manuscript studies (207).

The limited success of this volume reflects, not sloppy work on the part of its contributors, but rather what is now seen as scholarship's failure to really address the question of "music and society." Most of the work on which it depends is now close to ten years old, and in many cases older, and this impediment shows. In the past decade, a good deal of study has been undertaken using approaches which will eventually make its still-needed successor, or second edition, a much greater achievement.

Terry Brown

Curtis Price, ed. The Early Baroque Era: From the Late 16th Century to the 1660s. Music and Society. Englewood Cliffs, NJ: Prentice-Hall Inc., 1993. xiv, 400 pp. ISBN 0-13-223835-7 (hardcover), ISBN 0-13-223793-8 (paperback), referred to below as I:

1. Curtis Price, "Music, Style and Society"; 2. Tim Carter, "The North Italian Courts"; 3. Silke Leopold, "Rome: Sacred and Secular"; 4. Ellen Rosand, "Venice, 1580-1680"; 5. Anne Schnoebelen, "Bologna, 1580 1700"; 6. John Walter Hill, "Florence: Musical Spectacle and Drama, 1570-1650"; 7. Theophil Antonicek, "Vienna, 1580-1705"; 8. Gina Spagnoli, "Dresden at the Time of Schutz"; 9. George J. Buelow, "Protestant North Germany"; 10. Martin Medforth, "The Low Countries"; 11. Catherine Massip, "Paris, 1600-61"; 12. Marcelle Benoit, 